\title{
APLIKASI PENJUALAN BUKU PADA KOPERASI LESTARI SMA NEGERI 5 BANDAR LAMPUNG
}

\author{
Sulistiyono*1 \\ Jl. Zainal Abidin Pagar Alam No. 26 \\ Labuhan Ratu Bandar Lampung 35142
}

\begin{abstract}
Perkembangan perangkat keras dan perangkat lunak dewasa ini sangat mempengaruhi seluruh aspek kehidupan yang berkaitan dengan informasi dan teknologi. Kebutuhan akan informasi yang akurat merupakan hal yang sangat penting sebagai media pendukung dalam pengambilan keputusan. Koperasi Lestari merupakan suatu badan yang bergerak dalam bidang penjualan, sehingga memerlukan suatu sistem yang dapat mendukung untuk memonitoring kegiatan transaksi penjualan. Pengelolaan data penjualan pada Koperasi Lestari SMA Negeri 5 Bandar Lampung masih dilakukan secara manual dan komputerisasi menggunakan Microsoft excel hanya digunakan untuk membuat rekap penjualan perbulan. Proses pengolahan data penjualan yang dilakukan secara manual dan komputerisasi yang terbatas, mengakibatkan sering terjadinya kesalahan dalam pembuatan laporan penjualan. Kesalahan dalam pembuatan laporan penjualan perbulan disebabkan kurangnya ketelitian. Perancangan sistem komputerisasi Program Aplikasi Penjualan Buku pada Koperasi Lestari SMA Negeri 5 Bandar Lampung dapat memberikan kemudahan-kemudahan bagi petugas koperasi dalam melakukan proses input data buku, input data siswa, input transaksi pengambilan buku, input transaksi pembayaran buku, pencetakan laporan-laporan dan penyajian informasi-informasi yang lebih akurat.
\end{abstract}

\section{PENDAHULUAN}

\subsection{Latar Belakang}

Perkembangan perangkat keras dan perangkat lunak dewasa ini sangat mempengaruhi seluruh aspek kehidupan yang berkaitan dengan informasi dan teknologi. Data adalah merupakan suatu informasi yang dapat dijadikan sebagai media untuk memonitoring, mengevaluasi kinerja, baik di dalam suatu organisasi atau instansi. Kebutuhan akan informasi yang akurat merupakan hal yang sangat penting sebagai media pendukung didalam pengambilan keputusan. Sebagai salah satu cara untuk mendapatkan informasi yang akurat dalam suatu organisasi atau instansi adalah dengan membuat suatu perancangan sistem yang baik dan mendukung, untuk dapat mengumpulkan, mengolah, dan meyimpan datadata yang dibutuhkan melalui peralatan komputer. Koperasi Lestari merupakan suatu badan yang bergerak dalam bidang penjualan, sehingga memerlukan suatu sistem yang dapat mendukung untuk memonitoring keadaan keuangan dan persediaan barang. Pengelolaan data penjualan merupakan salah satu sistem yang dapat digunakan untuk melihat jumlah uang yang ada kemampuan konsumen dalam pembelian barang.
Pengelolaan data penjualan pada Koperasi Lestari SMA Negeri 5 Bandar Lampung oleh petugas koperasi khususnya bagian penjualan yang masih dilakukan secara manual dan komputerisasi menggunakan Microsoft excel yang hanya digunakan untuk membuat rekap daftar penjualan perbulan. Laporan penjualan perbulan akan menjadi suatu data atau informasi dalam proses penjualan yang dilakukan setiap awal bulan. Proses pengolahan data penjualan yang dilakukan secara manual dan komputerisasi yang terbatas tersebut, mengakibatkan sering terjadi kesalahan dalam pembuatan laporan penjualan yang dilakukan oleh petugas koperasi, ketidaksesuaian laporan penjualan yang dilakukan petugas koperasi dengan yang sesungguhnya, tidak efektif karena pekerjaan yang sama dilakukan secara berulang-ulang dan tidak efisien karena waktu yang diperlukan untuk memproses suatu laporan relatif cukup lama, kesalahan dalam pembuatan laporan penjualan perbulan disebabkan kurangnya ketelitian. Proses tersebut juga tidak dapat memberikan laporan evaluasi kinerja petugas koperasi dalam pelaksanaan kegiatan penjualan sehingga kesulitan dalam pengambilan keputusan.

Berdasarkan permasalahan tersebut, maka penulis tertarik untuk membuat suatu aplikasi pengolahan data penjualan secara komputerisasi 
dengan mengambil judul penelitian "Aplikasi Penjualan Buku pada Koperasi Lestari SMA Negeri 5 Bandar Lampung". Sesuai dengan latar belakang di atas, maka dapat dirumuskan masalah sebagai berikut : Bagaimana membuat suatu aplikasi pengolahan data transaksi penjualan buku agar dapat menyajikan laporan data sales, laporan data siswa, laporan pengambilan buku, laporan pembayaran buku, laporan stok buku dan laporan piutang penjualan secara akurat ?. Penulis memberikan batasan masalah pada pembahasan dalam penelitian ini, dengan tujuan untuk meyederhanakan persoalan yang dihadapi dan tidak menyimpang dari yang diinginkan.

1. Analisis sistem hanya terbatas pada proses pengolahan data transaksi penjualan buku pada Koperasi Lestari SMA Negeri 5 Bandar Lampung.

2. Pengembangan sistem hanya ditentukan pada pengolahan data transaksi penjualan buku pada Koperasi Lestari SMA Negeri 5 Bandar Lampung. Tujuan penelitian ini adalah untuk membuat aplikasi program pengolahan data penjualan buku pada Koperasi Lestari SMA Negeri 5 Bandar Lampung. Dengan adanya program pengolahan data penjualan secara komputerisasi diharapkan dapat memberikan laporan yang akurat untuk menunjang proses pengambilan keputusan serta dapat menjadi indikator dalam informasi keadaan keuangan koperasi.

Manfaat dari penelitian ini adalah sebagai berikut :

1. Sebagai alat bantu bagi petugas bagian keuangan Koperasi Lestari SMA Negeri 5 Bandar Lampung dapat mengefisienkan pekerjaan dan mengurangi tingkat kesalahan.

2. Memberikan laporan data sales, laporan data siswa, laporan pengambilan buku, laporan pembayaran buku, laporan stok buku dan laporan piutang penjualan laporan keuangan yang akurat kepada ketua koperasi untuk dijadikan dasar dalam pengambilan keputusan.

3. Sebagai pertimbangan dalam pengembangan sistem informasi koperasi dan pemanfaatan teknologi sistem informasi.

Kegiatan penelitian ini dilakukan pada Koperasi Lestari SMA Negeri 5 Bandar Lampung. Ruang lingkup pembahasan pada penelitian ini adalah mengenai perancangan sistem pengolahan data penjualan buku.

\section{METODE}

"Metode penelitian adalah merupakan cara ilmiah

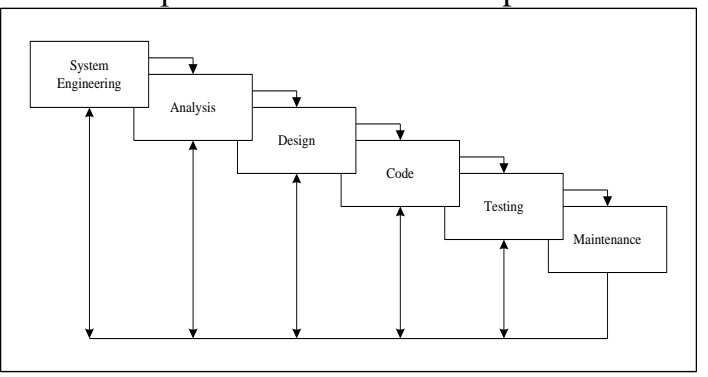

untuk mendapatkan informasi dengan tujuan dan kegunaan tertentu".

(http://pasca-

unsoed.or.id/adm/data/Metodologi\%20Penelitian)

Metode yang digunakan dalam pengembangan sistem yaitu dengan siklus klasik/air terjun dengan tahapantahapan yang terdiri dari Analisis dan Rekayasa Sistem, Analisis Persyaratan, Perancangan, Coding (Penulisan Program), Pengujian, dan Pemeliharaan, yang ditunjukkan pada gambar di bawah ini :

\section{Karakteristik Sistem}

Suatu sistem mempunyai karakteristik atau sifat-sifat tertentu, yaitu

1. Komponen Sistem (Components)

Suatu sistem terdiri dari sejumlah komponen yang saling berinteraksi, yang artinya saling bekerjasama membentuk suatu kesatuan.

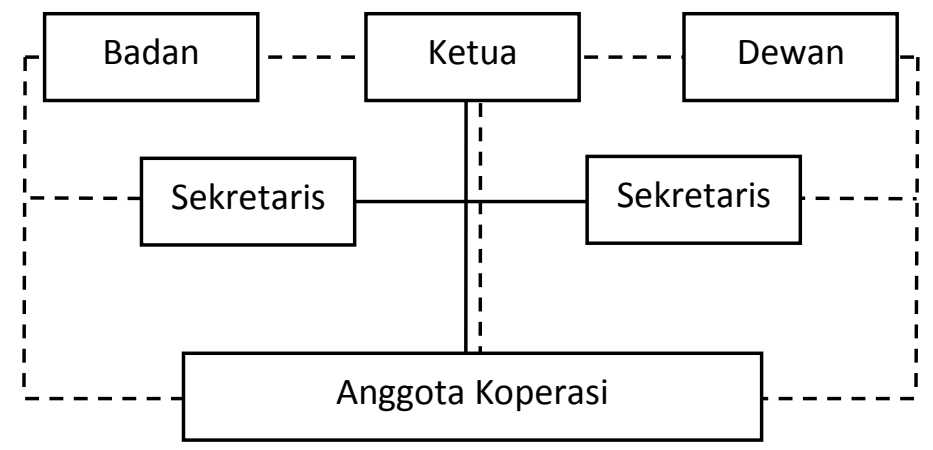

2. Batasan Sistem (Boundary)

Merupakan daerah yang membatasi antara suatu sistem dengan sistem yang lainnya atau dengan lingkungan luarnya. 
3. Lingkungan Luar Sistem (Environment)

Yaitu apapun di luar batas dari sistem yang mempengaruhi operasi sistem.

\section{Penghubung Sistem (Interface)}

Merupakan media yang menghubungkan antara satu sub sistem dengan sub sistem yang lainnya.

5. Masukan Sistem (Input)

Adalah energi yang dimasukkan ke dalam sistem. Masukan dapat berupa perawatan dan sinyal.

6. Keluaran Sistem (Output)

Adalah energi yang diolah dan diklasifikasikan menjadi keluaran yang berguna.

7. Pengolahan Sistem (Process)

Suatu sistem dapat mempunyai suatu bagian pengolah atau sistem sendiri sebagai pengolahnya. Pengolah yang akan merubah masukan menjadi keluaran.

\section{Sasaran Sistem (Objectives)}

Yaitu agar dapat tercapainya cara kerja atau kinerja yang efektif dan efisien.

Data adalah fakta mengenai objek, orang, dll. (data dapat dinyatakan dengan nilai, angka, deretan karakter, atau simbol)”. (Abdul Kadir, 1999:11).

Berdasarkan pengertian di atas maka dapat disimpulkan bahwa data adalah fakta-fakta pikiran atau pendapat yang belum memiliki makna yang dapat dimanfaatkan. Data ini merupakan bahan mentah dari informasi. Jadi untuk memanfaatkan informasi yang dibutuhkan kita harus terlebih dahulu mendapatkan data.

\section{Proses Pengolahan Data}

Data

Informasi

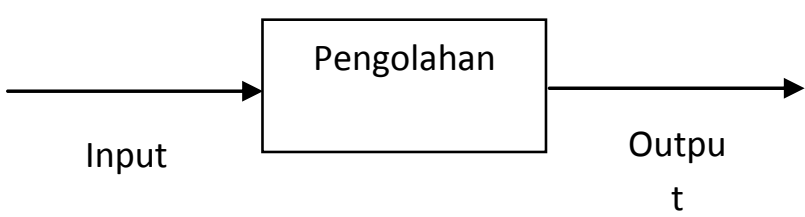

\section{ANALISIS DAN PERANCANGAN SISTEM}

\section{Prosedur Aplikasi Penjualan Buku pada Koperasi Lestari SMA Negeri 5 Bandar Lampung}

Pada aplikasi penjualan buku di Koperasi Lestari SMA Negeri 5 Bandar Lampung terdapat 3 entitas yang terlibat, yaitu Petugas Koperasi, Siswa dan Ketua Koperasi. Adapun prosedur Aplikasi Penjualan Buku pada Koperasi Lestari SMA Negeri 5 Bandar Lampung dimulai ketika siswa yang membutuhkan buku pelajaran yang akan digunakan sebagai penunjang dalam kegiatan belajar datang ke Koperasi Lestari SMA Negeri 5 Bandar Lampung. Untuk lebih jelasnya dapat dijelaskan sebagai berikut:

1. Siswa yang akan membeli buku pelajaran datang ke ruang Koperasi Lestari SMA Negeri 5 Bandar Lampung, siswa kemudian memilih buku pelajaran yang menjadi kebutuhannya. Setiap siswa dapat membeli buku seluruh mata pelajaran pada tingkatan kelas yang bersangkutan.

2. Siswa yang akan membeli buku, menyerahkan kartu pelajar dan buku yang akan dibeli dan kepada petugas koperasi.

3. Petugas koperasi memeriksa kartu pelajar dan buku yang akan dibeli oleh siswa, kemudian memasukkan data siswa dan data buku yang akan dibeli oleh siswa kedalam komputer.

4. Petugas koperasi membuat tanda pengambilan buku. Petugas koperasi kemudian menyerahkan tanda pengambilan buku, kartu pelajar dan bukubuku yang akan dibeli kepada siswa.

5. Siswa yang akan membayar buku, menyerahkan kartu pelajar dan tanda pengambilan buku kepada petugas koperasi.

6. Petugas koperasi mengecek data pada komputer berdasar data kartu pelajar dan tanda pengambilan buku dari siswa.

7. Petugas koperasi menerima uang pembayaran buku dan membuatkan tanda pembayaran/kwitansi buku kemudian menyerahkan kartu pelajar, kwitansi, tanda pengambilan buku kepada siswa.

Penjelasan alur sistem di atas dapat digambarkan seperti tampak pada gambar :

\section{Struktur Kepengurusan Koperasi Lestari SMA Negeri 5 Bandar Lampung}




\section{RANCANGAN CALCULATOR}

\section{DIAGRAM KONTEKS}

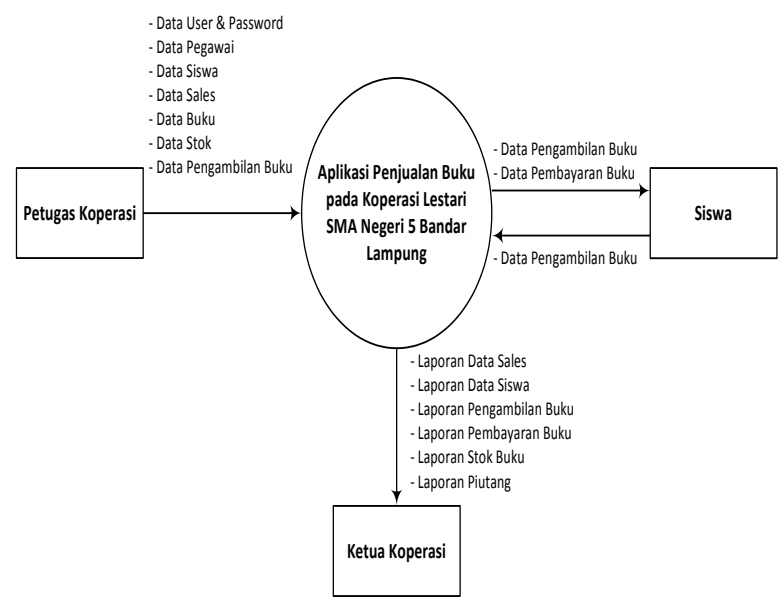

FROM LOGIN

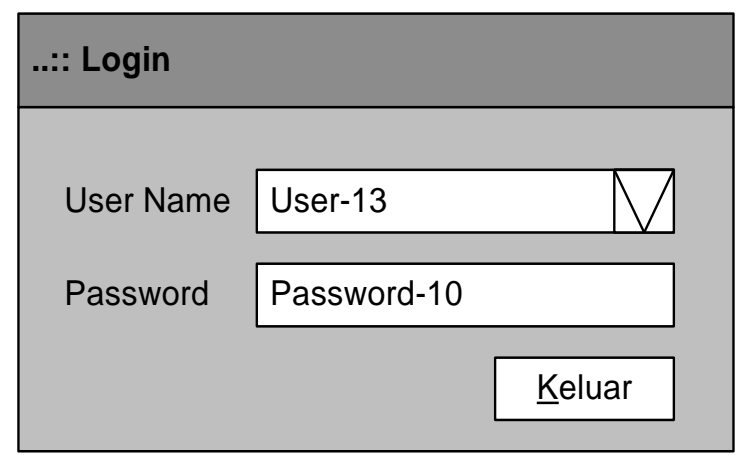

FROM INPUT SISWA

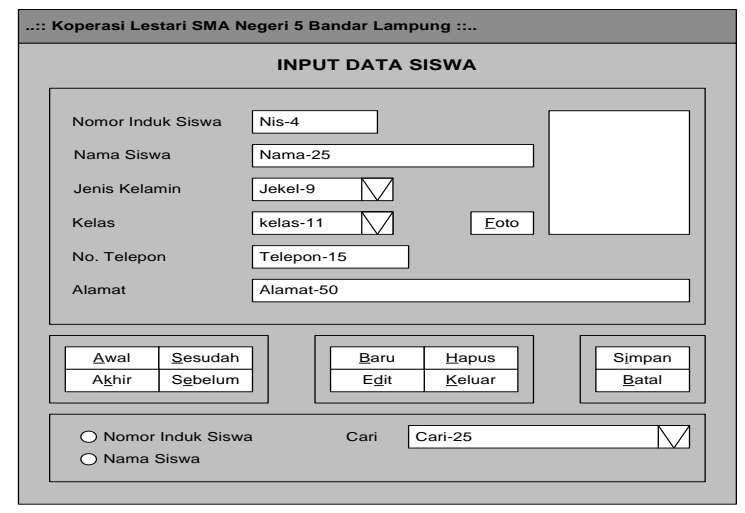

Fasilitas calculator digunakan untuk melakukan berbagai macam perhitungan apabila diperlukan dalam transaksi penjualan buku pada Koperasi Lestari SMA Negeri 5 Bandar Lampung. Program ini merupakan accessories yang terdapat pada windows. Tampilan calculator dapat dilihat pada gambar

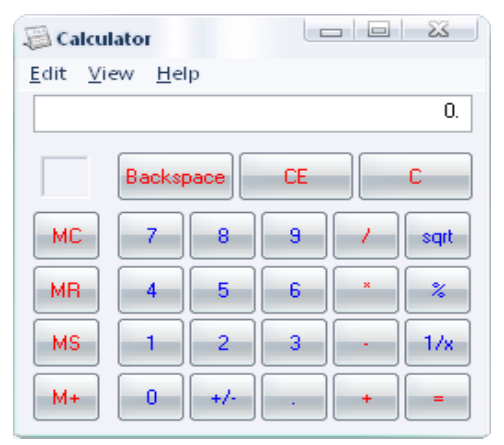

\section{RANCANGAN LAPORAN DATA SISWA}

Rancangan laporan data siswa digunakan untuk mengecek semua data siswa anggota Koperasi Lestari SMA Negeri 5 Bandar Lampung.

\section{IMPLEMENTASI DAN PEMBAHASAN}

Setelah melalui objek penelitian dengan mengikuti prosedur yang ada, maka hasil yang didapat dari penelitian ini adalah suatu program untuk "Aplikasi Penjualan Buku pada Koperasi Lestari SMA Negeri 5 Bandar Lampung". Sistem ini dibuat dengan aplikasi pemrograman Visual Basic 6.0 dengan menggunakan database Microsoft Access dan menggunakan Crystal Report untuk membuat laporan. Aplikasi penjualan buku ini dibuat untuk mempermudah kerja karyawan/petugas koperasi dalam pengelolaan proses transaksi pembelian dan pembayaran buku pada Koperasi Lestari SMA Negeri 5 Bandar Lampung.

Pengelolaan proses transaksi yang baik akan berdampak pada pembuatan laporan yang lebih cepat, lebih baik dan lebih akurat sehingga kesalahankesalahan dalam pembuatan laporan tidak terjadi kembali sebagaimana tujuan dari adannya sistem komputerisasi adalah untuk mengatasi kelemahankelemahan sistem lama yang bersifat manual. Program 
Aplikasi Penjualan Buku pada Koperasi Lestari SMA Negeri 5 Bandar Lampung terdiri dari satu menu utama dan beberapa submenu untuk memudahkan proses input dan pengolahan datanya. Untuk lebih jelasnya penulis akan menggunakan bagian-bagian yang ada dalam program aplikasi penjualan buku ini.

\section{PEMBAHASAN}

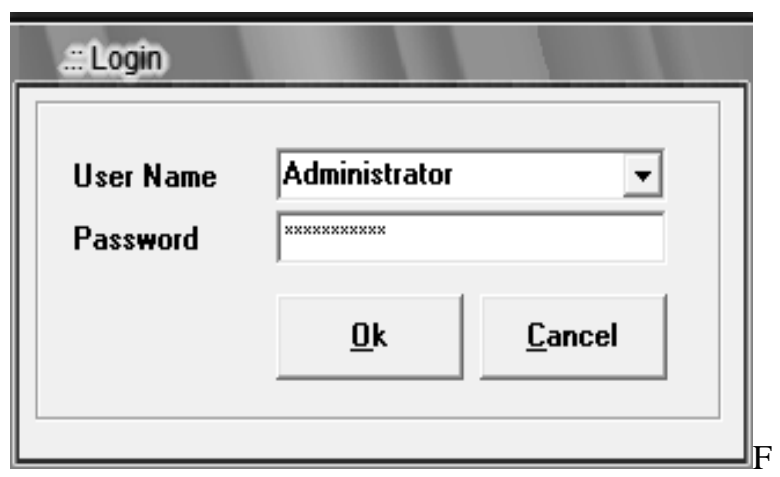

ROM LOGIN

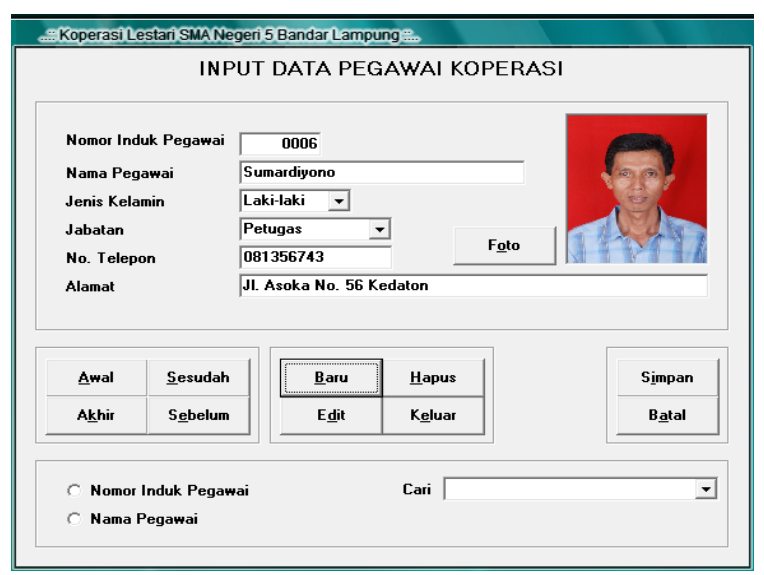

\section{FORM PENGIMPUTAN DATA PEGAWAI KOPERASI}

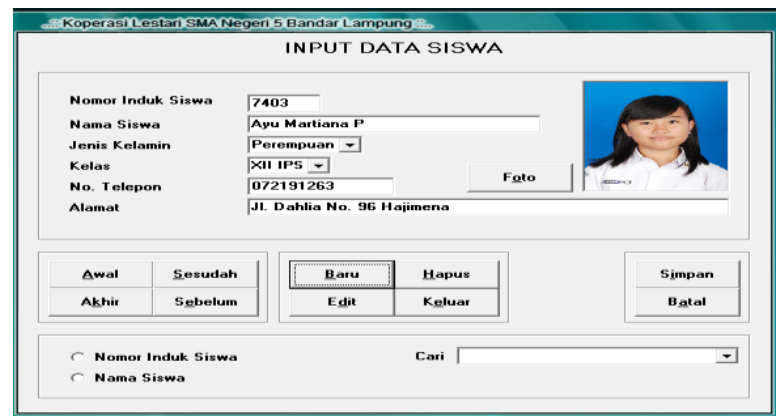

Form Input Data Siswa digunakan untuk meng-input data siswa anggota Koperasi Lestari SMA Negeri 5 Bandar Lampung. Tampilan form input data siswa dapat dilihat pada gambar di bawah ini :Form Input Data Sales Buku digunakan untuk meng-input data sales buku yang menyuplai buku ke Koperasi Lestari SMA Negeri 5 Bandar Lampung.

Form Input Data Buku digunakan untuk meng-input data buku Koperasi Lestari SMA Negeri 5 Bandar Lampung.

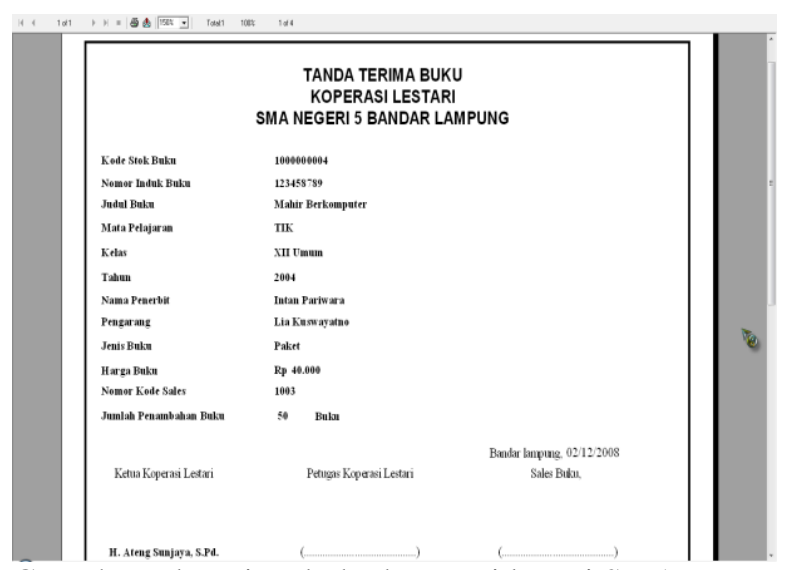

Contoh tanda terima buku koperasi lestari SMA

Negeri 5 Bandar Lampung.

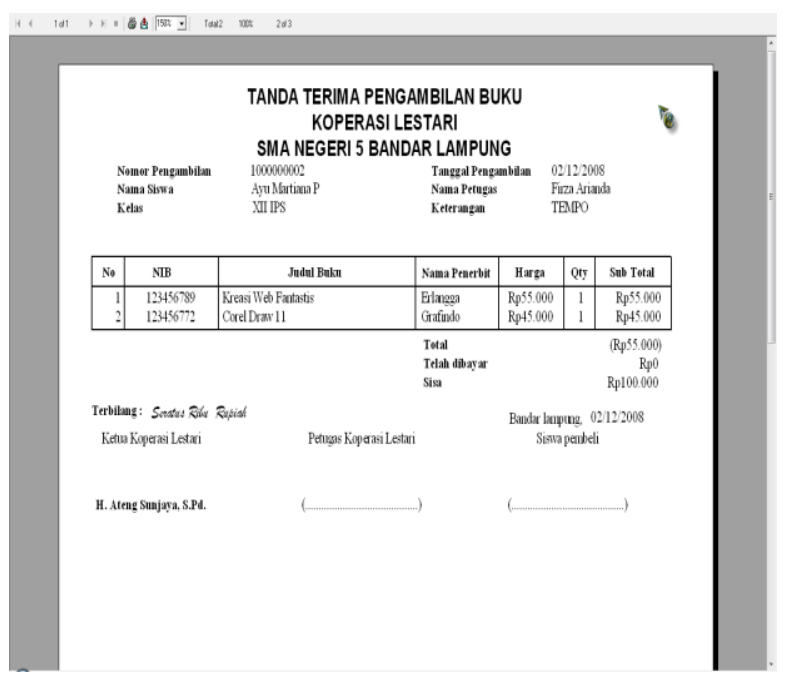

Pembuatan tanda terima pengambilan buku cukup hanya dengan meng-klik tombol Cetak

Menu Help berisi tentang petunjuk penggunaan program Aplikasi Penjualan Buku pada Koperasi 
Lestari SMA Negeri 5 Bandar Lampung. Adapun tampilan Help dapat dilihat pada gambar di bawah ini :

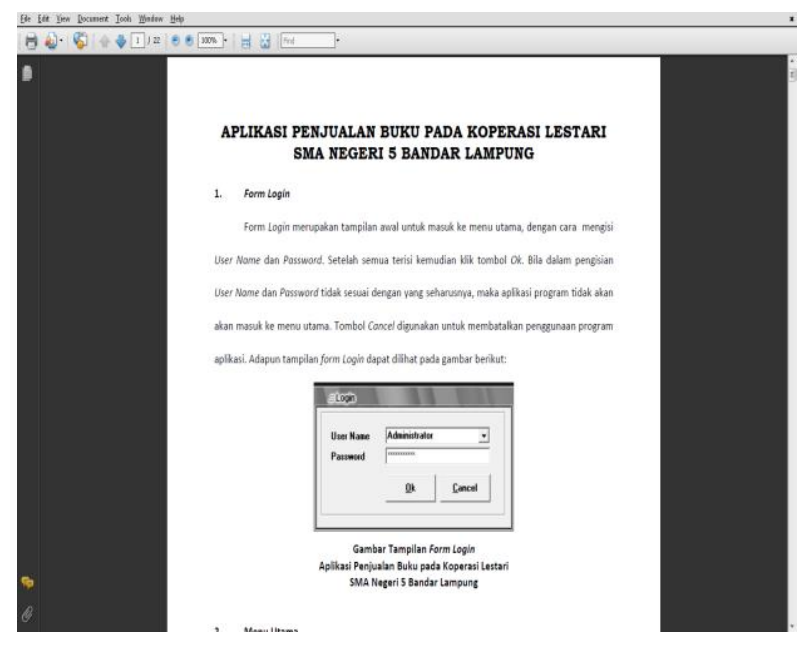

\section{Kesimpulan}

Berdasarkan analisis pembahasan hasil penelitian tentang pengolahan data transaksi penjualan buku pada Koperasi Lestari SMA Negeri 5 Bandar Lampung, maka penulis dapat mengambil simpulan sebagai berikut:

1. Perancangan sistem komputerisasi Program Aplikasi Penjualan Buku pada Koperasi Lestari SMA Negeri 5 Bandar Lampung dapat memberikan kemudahan-kemudahan bagi petugas koperasi dalam melakukan proses input data buku, input data siswa, input transaksi pengambilan buku, input transaksi pembayaran buku, pencetakan laporan-laporan dan penyajian informasi-informasi yang lebih akurat.

2. Selama ini pengolahan informasi pada Koperasi Lestari SMA Negeri 5 Bandar Lampung masih dilakukan secara manual, sehingga memerlukan waktu dalam pencarian data dan pembuatan laporan-laporan.

3. Untuk menggunakan program Aplikasi Penjualan Buku pada Koperasi Lestari SMA Negeri 5 Bandar Lampung memerlukan dukungan dan penyediaan perangkat teknologi informasi/komputer yang memadai jika dibandingkan hanya dengan cara manual yang hanya memerlukan beberapa buku untuk proses pencatatan. Selain itu penggunaan perangkat teknologi informasi memerlukan perawatan/maintenance untuk tetap menjaga Saran berfungsinya alat-alat yang digunakan.

Setelah melakukan berbagai pengamatan selama melakukan kegiatan penelitian di Koperasi Lestari SMA Negeri 5 Bandar Lampung dan selama kegiatan perancangan program Aplikasi Penjualan Buku pada Koperasi Lestari SMA Negeri 5 Bandar Lampung, penulis dapat memberikan saran-saran yang diharapkan dapat bermanfaat antara lain sebagai berikut:

1. Pengolahan data penjualan buku pada Koperasi Lestari SMA Negeri 5 Bandar Lampung sebaiknya menggunakan aplikasi penjualan buku yang penulis buat untuk memperlancar proses pengolahan data penjualan maupun dalam pembuatan laporan-laporan.

2. Perangkat teknologi informasi/komputer perlu memperhatikan spesifikasi komputer yang memadai sehingga komputer memiliki kemampuan yang cukup untuk menjalankan program Aplikasi Penjualan Buku pada Koperasi Lestari SMA Negeri 5 Bandar Lampung.

3. Perlu adanya pelatihan bagi petugas penjualan dan petugas penerima pembayaran buku agar dapat menggunakan Aplikasi Penjualan Buku pada Koperasi Lestari SMA Negeri 5 Bandar Lampung.

4. Perlu adanya tindak lanjut dalam pengembangan dan penyempurnaan program Aplikasi Penjualan Buku pada Koperasi Lestari SMA Negeri 5 Bandar Lampung menjadi sistem yang lebih baik, karena penulis menyadari masih banyak terdapat kekurangan-kekurangan dan keterbatasanketerbatasan dalam pembuatan program aplikasi ini. Adapun kekurangan dan keterbatasan tersebut adalah : program aplikasi penjualan buku pada koperasi lestari SMA Negeri 5 Bandar Lampung merupakan sistem yang stand alone sehingga perlu adanya pengembangan menjadi sistem client-server. 


\section{DAFTAR PUSTAKA}

Setelah melakukan berbagai pengamatan selama melakukan kegiatan penelitian di Koperasi Lestari SMA Negeri 5 Bandar Lampung dan selama kegiatan perancangan program Aplikasi Penjualan Buku pada Koperasi Lestari SMA Negeri 5 Bandar Lampung, penulis dapat memberikan saran-saran yang diharapkan dapat bermanfaat antara lain sebagai berikut:

1. Pengolahan data penjualan buku pada Koperasi Lestari SMA Negeri 5 Bandar Lampung sebaiknya menggunakan aplikasi penjualan buku yang penulis buat untuk memperlancar proses pengolahan data penjualan maupun dalam pembuatan laporan-laporan.

2. Perangkat teknologi informasi/komputer perlu memperhatikan spesifikasi komputer yang memadai sehingga komputer memiliki kemampuan yang cukup untuk menjalankan program Aplikasi Penjualan Buku pada Koperasi Lestari SMA Negeri 5 Bandar Lampung.

3. Perlu adanya pelatihan bagi petugas penjualan dan petugas penerima pembayaran buku agar dapat menggunakan Aplikasi Penjualan Buku pada Koperasi Lestari SMA Negeri 5 Bandar Lampung.

4. Perlu adanya tindak lanjut dalam pengembangan dan penyempurnaan program Aplikasi Penjualan Buku pada Koperasi Lestari SMA Negeri 5 Bandar Lampung menjadi sistem yang lebih baik, karena penulis menyadari masih banyak terdapat kekurangan-kekurangan dan keterbatasanketerbatasan dalam pembuatan program aplikasi ini. Adapun kekurangan dan keterbatasan tersebut adalah : program aplikasi penjualan buku pada koperasi lestari SMA Negeri 5 Bandar Lampung merupakan sistem yang stand alone sehingga perlu adanya pengembangan menjadi sistem client-server. 